\title{
The role of Discourse in the typology of downsteps: Evidence from Ebira and Ghotuo
}

Kolawole Adeniyi

Dept of Linguistics and African Languages, Obafemi Awolowo University, Nigeria

https://doi.org/10.36505/ExLing-2012/05/0001/000207

\begin{abstract}
Ebira and Ghotuo are three-tone languages of the Benue-Congo language family that have the downstep phenomenon. However, the behaviour of downstep in these languages goes beyond the scope of phonology. This paper reports that there are discourse factors that play significant roles in determining whether there is downstep or not in these languages. The factors include formality of speech, speech rate and certain other sociolinguistic factors. This paper reports with experimental evidence that depending on these factors, speakers of Ghotuo and Ebira, can, and do consciously block the phenomenon. Thus, it is argued that an adequate description of the phenomenon in the languages can only be achieved by relating it to the sociolinguistic factors already mentioned.
\end{abstract}

Key words: downstep, discourse, speech rate, experimental

\section{Introduction}

The downstep phenomenon occurs when the level of realisation of a tone is brought lower than its normal level by an intervening low tone that is no longer visible (Pulleyblank 1986). At the early stages of studies on terraced-level tone systems, the phenomenon was tied to two-tone systems such as Igbo, Tiv, Edo (Bini), Twi (Akan) among others, but later extended to three-tone languages such as Ebira and Ghotuo (Elugbe 1985; Adive 1989).

\section{Characteristics of Downstep}

There are, at least, two key characteristics of downstep; one is that the terracing it produces results in tonetic overlap between the contrastive levels in a system (La Velle 1974:170; Clements 1979: 540)

Tadadjeu (1974) also shows quite clearly that though a downstepped high may sound like a Mid, a good way of telling which (! $\mathrm{H}$ or $\mathrm{M})$ is by considering the height of the following tone, particularly a following high; if it is Mid, the High would rise without any inhibition whereas if it is a downstepped High, the following High cannot rise above it. Thus, the second major characteristic of downstep is its levelsetting ability (Armstrong 1968: 51-52; Clements 1979).

\section{Downstep in Ebira}

Ebira contrasts three levels, as seen in hú 'to drink,' $h u$ 'to uproot,' and hì 'to roast in open fire'

ExLing 2012: Proceedings of 5th Tutorial and Research Workshop on Experimental Linguistics, 27-29 August 2012, Athens, Greece 
Further, the downstep in Ebira affects the $\mathrm{M}$ and the $\mathrm{H}$. The downstepping is well pronounced at juncture, especially when a L, originally on the final vowel of a verb gets deleted before a non-low occurring as the initial vowel of a following noun. It can also result in attributive constructions where the deleted L could be after the juncture. In example (2), the pitch of the first syllable of ísórì is lowered from $124.5 \mathrm{~Hz}$ to $107.4 \mathrm{~Hz}$.

(1) j̀tá àdà $\rightarrow$ j̀tá!dá "father's friend"

(2) ô mè isórì $\rightarrow$ ô !misórì "he cooked food"

(3) rí ùrá $\rightarrow$ rú!rá "eat pork"

(5) ozí ìzé $\rightarrow$ ozíz!é "Ize's child"

(6) ô sì عnyá $\rightarrow$ ô!scnyá "he found the load"

\section{Downstep in Ghotuo}

Ghotuo contrasts three tone levels, as we have in j̀kpà "cock," j̀kpa "one", and skpá "lamp".

The Low and the Mid tones are downstepped in Ghotuo. The tonal behaviour of Ghotuo is complex in the attributive constructions, as well as in other grammatical forms such as sentences. For instance, as shown in the Noun-Demonstrative Associative construction (7), there is a floating high associative marker in the language that contributes highly to the behaviour of its tones, downstep inclusive.

Instrumental evidence shows that in (7) the pitch on 0 was reduced from $168 \mathrm{~Hz}$ to $155 \mathrm{~Hz}$. In (9), the pitch of !s is reduced by $19 \mathrm{~Hz}$, while in (10), the tone on !se is reduced by $11 \mathrm{~Hz}$ from that of jse.

(7) otà ass.H j̀nò $\rightarrow$ otá!nò "this tree"

(8) つ dé j̀məká $\rightarrow$ odó!moká "he bought an orange"

(9) つ dé ว̀s $\varepsilon$ na mhè $\rightarrow$ odó!s $\varepsilon$ nàmhè "he bought a cricket for me"

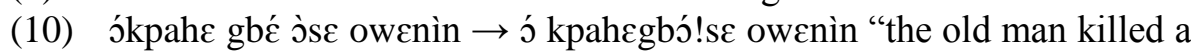
cricket yesterday"

\section{Discussion of the downstep in Ebira and Ghotuo}

Downstep in Ebira and Ghotuo is under the active control of the speaker, in which case it can be blocked by the speaker. In most cases, my informants interchanged between the presence and absence of it during data elicitation. Formality of speech is one reason for this. The most literate among my Ebira informants studied my word list before supplying the data. Downstep almost completely disappeared from the data she supplied. Secondly, seeing that the researcher is not Ebira made her automatically want to simplify her speech. In such situations, she restored all the Low tones that were supposed to be lost at junctures. 82-year-old pastor who also supplied data on Ebira had 
downstep when chatting with co-speakers of the language, but when speaking to the recorder, he inadvertently restored the supposedly lost Low tones. Ghotuo speakers also block downstep when speaking with nonspeakers of their language. Figures (1) and (2) show the same utterance rendered by one of my Ghotuo informants, one having downstep, the other not. Similar reports have been made about some related three-tone systems.

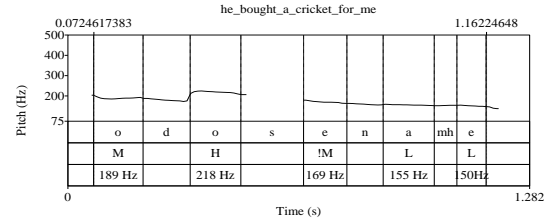

Figure 1. With downstep.

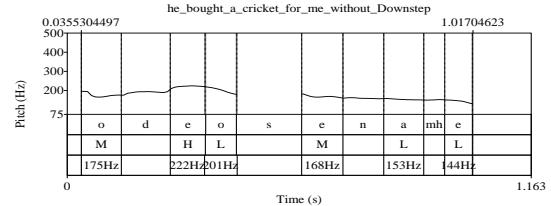

Figure 2. Without downstep.

\section{Discourse-related explanation of downstep in Ebira and Ghotuo}

Since downstep is speaker-controlled in Ebira and Ghotuo, there is the need to factor-in those discourse factors that determine when it is realised/blocked in order to achieve an adequate description of the phenomenon in the languages, because this is the only way the arbitrariness in its realisation can be captured phonetically. This is because of the possibility that these discourse factors are accommodated within the pitch range, and their effects reflected in the eventual phonetic realisations of tones. In tone languages, the pitch range still gives allowance for "things other than lexical tones" (Xu 2006). "While tones specify the pitch targets... of individual syllables, other aspects of the target approximation process are left unspecified, and hence available for manipulation to encode other communicative functions" (Xu 2006), which is what "the need to be understood by non-native speakers", or the formality of the context explore in these languages to resist the realisation of downstep (Cauldwell 2002).

I suspect that Ebira and Ghotuo, as well as the other three-tone systems in which downstep is constrained by discourse, are so because they acquired the downstep feature at a later stage than the two tone languages (Clements 1979: 541; Fromkin 1972: 60), and considering that the Proto Niger-Congo language is believed to be a two-tone language (Clements and Rialland, 2008:69), there are grounds that three-tone languages have diverged farther than two tone-languages in respect of tone, and are widening the gap by the development of downstep.

\section{Conclusion}

In this paper, I have reported that downstep in Ebira and Ghotuo is under the active control of the speaker. I argued that there are discourse factors that play significant roles in the determination of downstep in these languages, 
and that in order to give adequate description of this downstep, one needs to look beyond the scope of phonology and factor-in these discourse factors, such as formality of speech and the sheer desire to obey the cooperative principle. Thus, I have shown that Ebira and Ghotuo are neither typical terraced-level nor typical discrete-level in nature (Connell 2009:239). This paper is, therefore, a contribution to scholarship on the typology of tone systems. However, more works still need to be done on the issues raised and other three-tone languages of the Benue-Congo family need to be studied to see how general this position can be.

\section{Notes}

1. Downstep in Yala (Ikom) can be neutralised in emphatic or enthusiastic utterances (Armstrong 1968); "Downstep in Yoruba is constrained in strange ways still largely unclear today" (Elugbe 1995:73).

\section{References}

Adeniyi, K. 2009. The Typology of Three-Tone Systems:Ebira, Ghotuo, Yala (Ikom), and Yoruba. M.A. Project, Department of Linguistics and African Languages, University of Ibadan, Ibadan, Nigeria.

Adive, J. R. 1989. The verbal Piece in Ebira. SIL.

Cauldwell, R. 2002. The functional irrhythymicality of spontaneous speech: a discourse view of speech rhythms. Apples - Journal of Applied Language Studies 2 (1) $1-24$.

Clements, G.N. and Rialland, A. 2008. Africa as a phonological area. In: Heine, B. and Nurse, D. (Eds.) A Linguistic geography of Africa. Cambridge: Cambridge University Press, $36-85$.

Connell, B. 2009. African tone systems: terracing versus discrete-level languages and the tonal space. In Urua, E. Ekpenyong M. and Ahoua F. (Eds). 2009. Language development beyond borders. 249-269. Uyo, Glomasoft.

Elugbe, B. 1985. The Tone System of Ghotuo. Cambridge Papers in Phonetics and Experimental Linguistics 4: 1-21.

Elugbe, B. 1995. The 'Assimilated low tone' in Ghotuo. In Owolabi, K. (Ed.). 1995. Language in Nigeria. Ibadan, Group publishers, 68-74.

Fromkin, V.A. 1972. Tone features and tone rule. Studies in African Linguistics, 3 (1) $47-76$.

Yi, Xu 2006. Tone in connected discourse. In Brown, K. (Ed.) Encyclopedia of language and linguistic, $2^{\text {nd }} \mathrm{Ed}$. Oxford, Elsevier. 